\title{
KNOWLEDGE OF THE BUSINESS ENVIRONMENT: EXPLORING ENGAGEMENT WITH AND DISCRIMINATION BETWEEN BUSINESS MEDIA AMONG FIRST-YEAR AND FINAL-YEAR STUDENTS
}

\author{
John Doran, Margaret Healy, Maeve McCutcheon and Steve O'Callaghan \\ University College Cork
}

\begin{abstract}
Students' broad knowledge of the business environment offers opportunities Sto lecturers to bring realism and context to disciplinary concepts; however, greater understanding of existing student practices is needed. This study compares first- and fourth-year Accounting and Finance students' knowledge of the business environment, and their engagement with and discrimination between various business media. Using a survey methodology, data were collected from first- and fourth-year students at one university. The findings indicate fourth years have greater knowledge of the business world and levels of engagement with business media. There was no difference between years as to the level of discrimination between different media sources. The findings also indicate that males have greater knowledge of the business world than females, although there is little difference in their levels of engagement and discrimination.
\end{abstract}

\section{INTRODUCTION}

Business knowledge provides the context in which professional accountants work and within which businesses operate (International Federation of Accountants, 2010). As students prepare for careers as professional accountants, the International Federation of Accountants (IFAC) has called for the development of their capacity to locate, understand and organise information from a variety of sources, as well as intellectual skills such as problem solving and critical reasoning (International Federation of Accountants, 2010). In the context of accounting education particularly, International Education Standard 3 - Professional Skills and General Education 
Doran, Healy, McCutcheon and O'Callaghan

(International Federation of Accountants, 2010) - points to the importance of a broader curriculum and of students having knowledge of the world outside of the traditional curriculum of the accounting, finance and other modules they are studying. Specifically, the standard states that professional accountants of the future need to be:

\footnotetext{
... broad-minded individuals who think and communicate effectively and who have the basis for conducting inquiry, carrying out logical thinking and undertaking critical analysis. This foundation will enable candidates to make decisions in the larger context of society, to exercise good judgement and professional competence, to interact with diverse groups of people, to think globally, and to begin the process of professional growth (International Federation of Accountants, 2010, p. 48).
}

Knowledge of the business environment is facilitated (at least in part) by engagement with various business media. Accounting educators encourage students to keep abreast of business and current affairs but there has been little empirical evidence to date regarding Irish students' engagement with, and discrimination between, business media. While such a focus differs from the usual academic concerns of lecturers, it is clearly fundamental to the context within which Accounting and Finance students will operate in their future careers and therefore deserving of greater attention. The research objective of this study is to explore students' knowledge of the business environment; to document students' engagement with and discrimination between various business media; and to consider the extent to which these differ between first-year students, commencing their studies, and fourth-year students, who could be expected to demonstrate higher levels of awareness, through their being more employment/career focused. The paper contributes therefore to the establishment of a picture of student practices, enabling greater educator understanding of the level of awareness (or otherwise) of the broader business context which students bring to their studies.

The remainder of the paper is organised as follows: the next section reviews the prior research evidence of student engagement with and discrimination between business media; the choice of survey methodology is then described and the research findings are presented; and lastly the implications of these findings are discussed in the final section.

\section{LITERATURE REVIEW}

As the nature of information sources continues to evolve, students need to learn not just the requisite skills and knowledge demanded in their disciplinary context, but also the information literacy skills and capabilities necessary to independently interpret and use the growing array of data sources available to them (Graham and Metaxas, 2003). For example, McDowell (2002, p. 256), based on a phenomenographic study of lecturer perspectives on the role of electronic information in undergraduate education in a range of fields at three universities, states that: 
Accessing and using information resources is one of the ways in which students begin to act as independent learners, becoming involved in making choices, weighing evidence and coming to conclusions for themselves.

Information literacy consists of a set of skills enabling students to recognise, locate, evaluate and use the information needed to solve problems (Wong, Stelmaszewska, Barn, Bhimani and Barn, 2009). For many students research or information gathering is conducted by going to the internet, with internet sources preferred to traditional print sources (Metzger, Flanagin and Zwarun, 2003; Griffiths and Brophy, 2005). Wong et al. (2009, p. 36), writing from the perspective of librarians, state that the development of information literacy skills amongst Business and Economics students and researchers from three higher education institutes in the United Kingdom (UK) in their study was:

... too often dependent on the native wit of the student, the chance encounter with an enlightened academic who has emphasised skills development in a particular module or a cost-ineffective but very valuable one-to-one session with a librarian.

Connaway and Dickey (2010), in synthesising the outcomes of twelve major funded studies in the UK and the United States (US) conducted from a librarianship perspective, cite evidence across prior research for what they term 'the centrality of Google and other search engines' (Connaway and Dickey, 2010, p. 27), with speed and convenience being important factors determining user preferences. Online sources are deemed by students to be easier to locate and print, as well as being as more informative than hardcopy books and periodicals (Grimes and Boening, 2001). Graham and Metaxas (2003) surveyed 180 students from different class years who were all taking a 'Computers and the Internet' class. Their findings document how the students limited themselves to faithful reliance on a single search engine, with students in later years not being better internet researchers than students from earlier years. Using a sample of students taking a wide variety of subjects and at various stages in their third level studies, Griffiths and Brophy (2005) found 45 per cent of students in their sample used Google as their first means of locating information, trading quality of results against the time and effort spent on searching; only 10 per cent of the research sample used the library catalogue.

The information literacy skills of users are not as advanced as their digital literacy skills (Hampton-Reeves, Mashiter, Westaway, Lumsden, Day, Hewerston and Hart, 2009). Graham and Metaxas (2003) suggest that students may not even be aware of the effort required to critically evaluate the information they locate. While students are familiar with their chosen medium and confident in using it to retrieve information, they are less skilled in evaluating the credibility of that information. In using the internet, students have difficulty distinguishing between advertising and fact (Graham and Metaxas, 2003) and perceive electronic media differently when used for academic rather than social purposes (Cole, 2009; Madge, Meek, Wellens and Hooley, 2009). For example, in describing an action research project of practitioner experiences of using a wiki to promote student engagement within a final-year undergraduate information systems module, Cole (2009) reports that 68 
Doran, Healy, McCutcheon and O'Callaghan

per cent of the cohort had visited the wiki but not posted to it and suggests that the use of social technologies may not be deemed by students as useful in educational contexts. The implication for educators is that although students may be technologically savvy and digital natives in other spheres of their lives, engagement with new media needs to be fostered in relation to business and economic resources. This skills gap is seen as particularly problematic when lecturers overestimate students' abilities to apply the same standards of discrimination to sources as they themselves do (Grimes and Boening, 2001). Grimes and Boening (2001, p. 21), writing from the perspective of academic librarians, go so far as to state:

The unfettered availability of Web resources requires the use of critical thinking skills, in short supply among some students. Instructors should be convinced to spend some of their precious class time to help students hone their critical thinking skills and to use evaluative techniques to identify information sources. In fact, the identification and evaluation of information to solve problems should be a goal in and of itself, without necessarily being simply a step in the process of writing a research paper.

The search for insights into patterns of information retrieval and consumption is also reflected in research considering the extent to which online news consumption either displaces or complements existing traditional media. For example, Chan and Leung (2005), based on an exploratory email survey of 453 internet users across the general population, found that online news use was not replacing traditional news sources (defined as being television, newspapers and radio), but was used as a supplement to expand the coverage available to the user. However, more recently Ha and Fang (2012), based on 688 responses to a postal and online survey, found that as respondents' internet experience increased, online media sources displaced traditional media as sources of news. In respondents with five or more years of experience using the internet, weekly time spent using traditional media sources averaged 8.68 hours per week, compared to 11.63 hours for respondents with less than five years' internet use. Mitchelstein and Boczkowski (2010) suggest that the lack of conclusive findings regarding research into changing patterns of news consumption may have resulted from artificial distinctions made amongst media forms by prior researchers, with much of the existing research considering consumption of specific media, rather than integration amongst media types.

Gender and age differences in media engagement have been reported in the prior literature. Metzger et al. (2003), using an anonymous questionnaire administered to 356 undergraduate students enrolled in introductory communications courses at one US university, found that male students made greater use of the internet for news than female students, with the older students (in terms of programme progression) using newspapers less than younger students. D'Haenens, Jankowski and Heuvelman (2004) found that news consumption amongst 151 students in the social sciences from two universities in the Netherlands was more dependent on the category of news, reader gender and reader interest in the topic than on whether the source was in a traditional or online format. When measured in terms of time spent reading, the business section was the least popular amongst both male and female student respondents in the D'Haenens et al. (2004) study. In addition, higher levels 
of interest in business news were not reflected in higher levels of accurate recall of the content of articles, with females better able to recall business articles than males. No similar data are available in relation to Irish students.

Research has also yielded conflicting findings regarding the relationship between the use of, and the credibility assigned to, 'traditional' versus 'online' media sources, despite the extent to which this is perhaps an artificial distinction, as much information is now available via both platforms. In relation to electronic media, Wathen and Burkell (2002) state, following a review of prior research, that the source of information rather than the particular electronic media used may have a greater influence on the level of credibility ascribed to it by recipients. Flanagin and Metzger (2007) argue that credibility is a judgement made by the recipient of the information or content, rather than an objectively determined inherent property, and it applies equally to the assessment of online and traditional information sources. Over time, as users gain expertise in a given subject area, this in turn influences how the credibility assigned to various data sources is evaluated (Tseng and Fogg, 1999), suggesting students in later years, being more knowledgeable about the key business concepts of their discipline in comparison to first-year students, may act differently to students in earlier years of a programme. It may also be the case that students in later years are more externally focused, in terms of preparing for graduate recruitment processes, and thus more alert to the general business context associated with their studies.

The mass availability of multiple sources of information on current and topical events related to items of academic relevance and interest to students and educators necessitates increasing attention be paid to the importance of student engagement with, as well as students' abilities to discriminate between, information sources (Scholz-Crane, 1998). To aid students in the development of critical thinking abilities in the use, interpretation and application of such knowledge, lecturers first need to know what students know and how they choose and evaluate the sources of this information (Kirkwood and Price, 2005), as well as the extent to which they are engaged with the broader business environment. Student engagement with the business environment can be harnessed by lecturers to bring added realism and context to disciplinary concepts. This in turn can prompt students to deeper levels of engagement and enquiry, improving students' understanding of the theoretical underpinnings and practical applications of the concepts and principles they are studying.

There has been no prior research published on the engagement with and discrimination between business media of Irish Accounting and Finance students. This first paper is therefore necessarily broad and exploratory in nature, without directly comparable findings from prior research against which to consider the evidence gathered. Specifically, this study seeks (1) to identify the underlying level of business knowledge, engagement with media and discrimination between media sources of a group of Accounting and Finance students; (2) to establish whether there are differences in business knowledge, and media engagement and discrimination between first- and fourth-year students, as would be expected as students become more mature, experience work placement and become career-focused; and (3) to explore if the evidence of prior studies in these areas regarding gender differences is supported in Irish Accounting and Finance students, and, if so, whether these differences are equally apparent in first- and fourth-year students. The 
Doran, Healy, McCutcheon and O'Callaghan

research approach adopted and the hypotheses tested in order to achieve this objective are detailed in the following section.

\section{RESEARCH APPROACH}

This paper compares first- and fourth-year students' knowledge of the business environment, exploring their engagement with and discrimination between various business media. A combined quiz and survey instrument was used to meet this research objective, allowing access to a large number of respondents at a single point in time whilst respecting the exploratory nature of the underlying research objective (Saunders, Lewis and Thornhill, 2009). The quiz sought to establish respondents' level of knowledge of a broad range of economic and business institutions and personalities related to both domestic and international settings. The survey explored various aspects of student engagement with and discrimination between business media.

The quiz element of the research instrument contained three types of questions: photographs of business and economic personalities to be identified (eight in total), business and economic acronyms to be identified (ten), and a range of multiple choice questions (seven). Care was taken in the design of the quiz not to pose questions which directly related to material examinable on modules in their academic programmes. However, all the questions drafted by the researchers related to topical business and economic matters widely reported across a range of media at the time the survey was constructed and administered. People to be identified included Brian Lenihan, the then Minister for Finance, Sean FitzPatrick, the former chairman of Anglo Irish Bank, and Matthew Elderfield, the Financial Regulator. Acronyms in the quiz included NAMA (National Asset Management Agency), GNP (Gross National Product) and EFSF (European Financial Stability Facility). Multiple choice questions included 'Who is the President of the European Central Bank?' and 'What is the marginal rate on income tax in Ireland?' A total of 25 questions were used in the quiz to allow for a sufficient range of questions, while limiting the time required to answer them. A pilot copy of the research instrument was used to trial the questions for clarity and understanding. These responses do not form part of the research findings reported. Further details of the research instrument are available from the researchers, on request.

Using data gathered from the quiz section of the research instrument, the following hypotheses were tested.

$\mathbf{H}_{1}$ : Fourth-year respondents exhibit higher levels of knowledge of the business environment than first-year respondents.

$\mathbf{H}_{2}$ : Male and female respondents exhibit different levels of knowledge of the business environment.

The survey element of the research instrument addressed respondents' levels of engagement with, and discrimination between, sources of information about the 
business environment. Engagement was explored through a variety of questions: those concerning the frequency of use of a range of traditional and interactive media; those asking students about the type of newspaper last read; those asking students to list as many economic/business commentators as they could; and those exploring their usage of internet discussion fora. Each of these questions generated evidence of different aspects of engagement that could be compared across different student degree year groups and genders. In summary, the following would be indicative of strong levels of engagement with business media:

- High frequency of use of media sources

- The last newspaper read being a specialist business publication

- Ability to name a higher number of economic commentators

- Active engagement with business/economic discussion boards and blogs

For each of these measures of engagement, the literature would suggest the following hypotheses:

$\mathbf{H}_{3}$ : Fourth-year respondents exhibit higher levels of engagement with business media than first-year respondents.

$\mathbf{H}_{4}$ : Male and female respondents exhibit different levels of engagement with business media.

The survey asked respondents to rate, on a four-point scale from 'not reliable' to 'very reliable', a range of off-line and online media sources. The standard deviation of each respondent's reliability ratings of six print and television media sources is used as a proxy for their propensity to discriminate on the basis of reliability. In analysing the responses the researchers did not make subjective judgements as to the relative reliability of various media sources or the validity of the students' perceptions. Using data from these survey responses, the following hypotheses, derived from the researchers' review of prior research (presented earlier in this paper), were tested:

$\mathbf{H}_{5}$ : Fourth-year respondents exhibit higher levels of discrimination between sources of information about the business environment than first-year respondents.

$\mathbf{H}_{6}$ : Male and female respondents exhibit different levels of discrimination between sources of information about the business environment.

The research instrument was administered at the end of scheduled class periods to students in the first and fourth (final) years of undergraduate degrees in Accounting and Finance at one Irish university during the academic year 2010/2011. Table 1 presents the response rates for each of the first-year and fourth-year groups. Responses for Erasmus and other visiting students were excluded from the analysis 
Doran, Healy, McCutcheon and O'Callaghan

and are not included in Table 1. The potential population is the number of students registered for first year and fourth year respectively.

TABLE I: RESPONSE RATES

\begin{tabular}{lccc}
\hline \multicolumn{1}{c}{ Year } & Number of Respondents & Potential Population & Response Rate \\
\hline First Year & 73 & 126 & $58 \%$ \\
Fourth Year & 85 & 111 & $76 \%$ \\
Total & 158 & 237 & $66 \%$ \\
\hline
\end{tabular}

Students were briefed at the outset that this was not an exam or test; the researchers were simply looking for 'honest' answers. It is also noted that the timing of the data collection, November 2010, may be significant for the findings of this study. Ireland was in the midst of a fiscal and banking crisis; one month prior to the administration of the quiz and survey the government negotiated a bail-out package with the International Monetary Fund and European Union. During this period business and economic news was featured prominently in the general news media.

\section{RESEARCH FINDINGS}

\section{Knowledge of the Business World}

The quiz section of the research instrument contained three types of questions: photographs of business and economic personalities to be named, business and economic acronyms to be identified, and a range of multiple choice questions. All questions related to topical business and economic matters widely reported across a range of media at the time the research instrument was constructed and administered. The mean quiz scores and standard deviations are shown in Table 2.

TABLE 2: MEAN QUIZ SCORES

\begin{tabular}{lccc}
\hline & First Year & Fourth Year & Mann-Whitney p-value \\
\hline All Students & $46.30 \%(17.19 \%)$ & $58.43 \%(18.05 \%)$ & $0.00^{* *}$ \\
Male & $51.22 \%(17.38 \%)$ & $66.33 \%(18.11 \%)$ & \\
Female & $37.93 \%(13.42 \%)$ & $50.15 \%(13.95 \%)$ & \\
Mann-Whitney $p$-value & $0.00^{* *}$ & $0.00^{* *}$ & \\
\hline
\end{tabular}

** indicates statistical significance at $\mathrm{I} \%$ level

(Standard deviations are shown in parentheses)

The male quiz scores in both first and fourth year were normally distributed. The female quiz scores were not normally distributed in either cohort. Mann-Whitney $U$ tests were used to establish the statistical significance of differences in the samples. The differences in quiz scores between first- and fourth-year respondents was significant at the 1 per cent level, as were the differences in quiz scores between male and female respondents in both first and fourth years. Whether the samples differed in their performance in visual and non-visual parts of the quiz was also 
examined. The quiz comprised twenty-five questions in total, of which eight were photographs of economic or business personalities and seventeen were acronyms or multiple choice questions.

A wide variation in correct answering was noted between different questions. For example, on the visual questions the then Minister for Finance, Brian Lenihan, was correctly identified by 96 per cent and 90 per cent of first- and fourthyear respondents respectively; the Financial Regulator, Matthew Elderfield, was correctly identified by 8 per cent and 17 per cent respectively. On the acronym questions, 97 per cent and 83 per cent of first-year and fourth-year respondents respectively correctly identified APR (Annual Percentage Rate), while 0 per cent and 5 per cent respectively correctly identified EFSF (European Financial Stability Facility). Respondents performed better in the non-visual element of the quiz.

In the first-year sample the mean scores were 41 per cent and 49 per cent in the photographic and non-photographic questions respectively. This compared to 54 per cent and 60 per cent respectively in the fourth-year sample. The differences between the samples were significant at a 1 per cent level. In each year cohort males outscored females in both the photographic and non-photographic elements of the quiz. The disparity in gender scoring was significantly higher in the photographic element of the quiz for both year cohorts. The mean male and female scores in the photographic element were 54.9 per cent and 38.4 per cent respectively. The mean male and female scores in the non-photographic element were 58.6 per cent and 44.1 per cent respectively.

In summary, fourth-year students scored significantly higher than their firstyear counterparts, male respondents scored significantly higher than their female counterparts and male respondent scores were more dispersed than female scores. Male respondent outperformance was particularly pronounced in the visual element of the quiz. These findings provide support for $\mathrm{H}_{1}$ and $\mathrm{H}_{2}$.

\section{Engagement with Business Media}

Prior research has demonstrated that users access a variety of different information sources in a variety of different ways. The survey included a number of questions to explore this in the context of Irish first- and fourth-year Accounting and Finance students. Respondents were asked to indicate on a scale of Never, Rarely, Weekly or Daily how often they use a range of specified media sources. Table 3 shows the reported frequency of access to these specific media sources.

The first row of Table 3 reports the engagement with news media in general in the sub-samples. Fourth-year students are more engaged with news media, with a significant majority (67 per cent) accessing some form of news media daily and only 3 per cent rarely accessing news, compared to 36 per cent and 21 per cent respectively for first-year students. The frequency of use for all individual media sources is higher for fourth years than for first years. As can be seen from the 'Never' column, few fourth-year respondents are entirely disengaged from sources of news media whereas significant numbers of first-year students are.

Chi-square tests were used to determine whether the distribution of reported media use differed between first-year and fourth-year, and between male and female, sub-samples. The differences between first- and fourth-year respondents 
Doran, Healy, McCutcheon and O'Callaghan

TABLE 3: USE OF SPECIFIC MEDIA SOURCES IN FIRST AND FOURTH YEAR

\begin{tabular}{lcccccccc}
\hline & \multicolumn{2}{c}{ Never } & \multicolumn{2}{c}{ Rarely } & \multicolumn{2}{c}{ Weekly } & \multicolumn{2}{c}{ Daily } \\
& $\begin{array}{c}\text { First } \\
\text { Years }\end{array}$ & $\begin{array}{c}\text { Fourth } \\
\text { Years }\end{array}$ & $\begin{array}{c}\text { First } \\
\text { Years }\end{array}$ & $\begin{array}{c}\text { Fourth } \\
\text { Years }\end{array}$ & $\begin{array}{c}\text { First } \\
\text { Years }\end{array}$ & $\begin{array}{c}\text { Fourth } \\
\text { Years }\end{array}$ & $\begin{array}{c}\text { First } \\
\text { Years }\end{array}$ & $\begin{array}{c}\text { Fourth } \\
\text { Years }\end{array}$ \\
\hline $\begin{array}{l}\text { Any news media } \\
\begin{array}{l}\text { Newspapers } \\
\text { (paper) }\end{array}\end{array}$ & $0 \%$ & $0 \%$ & $21 \%$ & $3 \%$ & $43 \%$ & $30 \%$ & $36 \%$ & $67 \%$ \\
$\begin{array}{l}\text { Newspapers } \\
\text { (online) }\end{array}$ & $40 \%$ & $2 \%$ & $26 \%$ & $21 \%$ & $54 \%$ & $47 \%$ & $13 \%$ & $30 \%$ \\
$\begin{array}{l}\text { Radio } \\
\text { TV }\end{array}$ & $10 \%$ & $4 \%$ & $45 \%$ & $29 \%$ & $35 \%$ & $45 \%$ & $10 \%$ & $22 \%$ \\
\hline & $3 \%$ & $1 \%$ & $42 \%$ & $15 \%$ & $32 \%$ & $52 \%$ & $23 \%$ & $32 \%$ \\
\hline
\end{tabular}

were significant at the 1 per cent level for the use of online newspapers and television, and at the 5 per cent level for newspapers and radio. The difference in frequency of access to any news media was significant at the 1 per cent level. The differences in reported use of television between males and females were significant at a 5 per cent level; no other differences were significant. Ranking the media sources accessed on a daily basis by the two cohorts also suggests a different pattern of media use. Television is the primary news source for first years and online newspapers are the primary news source for fourth years, with each of these preferred to other media sources by wide margins. The first-year cohort primarily access newspapers in off-line (paper) form, with 40 per cent never accessing online newspapers, whereas fourth-year respondents prefer online newspapers. These findings indicate that there are significant differences between first- and fourth-year respondents in the reported frequency of use of news media, providing support for $\mathrm{H}_{3}$. Differences between males and females were generally not statistically significant. This evidence does not support $\mathrm{H}_{4}$.

Respondents were also asked to indicate which newspaper they last read. Responses were categorised as 'Specialist' - defined as publications where the content is primarily business and/or economics, 'General (news)' - defined as publications where the content is primarily general current affairs and 'General (non-news)' - defined as publications where the content is not primarily current affairs related. A comparison of first- and fourth-year groups is shown in Figure 1.

Figure 1 shows that 15 per cent of fourth-year respondents report that the last newspaper read was a specialist business and/or economic publication whereas only 3 per cent of first years report this. The number of first years reporting having last read a non-news (e.g. sports-/entertainment- focused) publication is higher than that of fourth years. Just over one-fifth (20.45 per cent) of male respondents reported last reading a specialist business publication compared to 9.76 per cent of females. Chi-square tests were performed on this data and the difference in the distribution of first years and fourth years reporting the last type of newspaper they read was significant at the 1 per cent level; the difference between male and female respondents was not statistically significant. The evidence presented on the type of last newspaper read supports $\mathrm{H}_{3}$ and does not support $\mathrm{H}_{4}$. 
FIGURE I: TYPE OF NEWSPAPER LAST READ

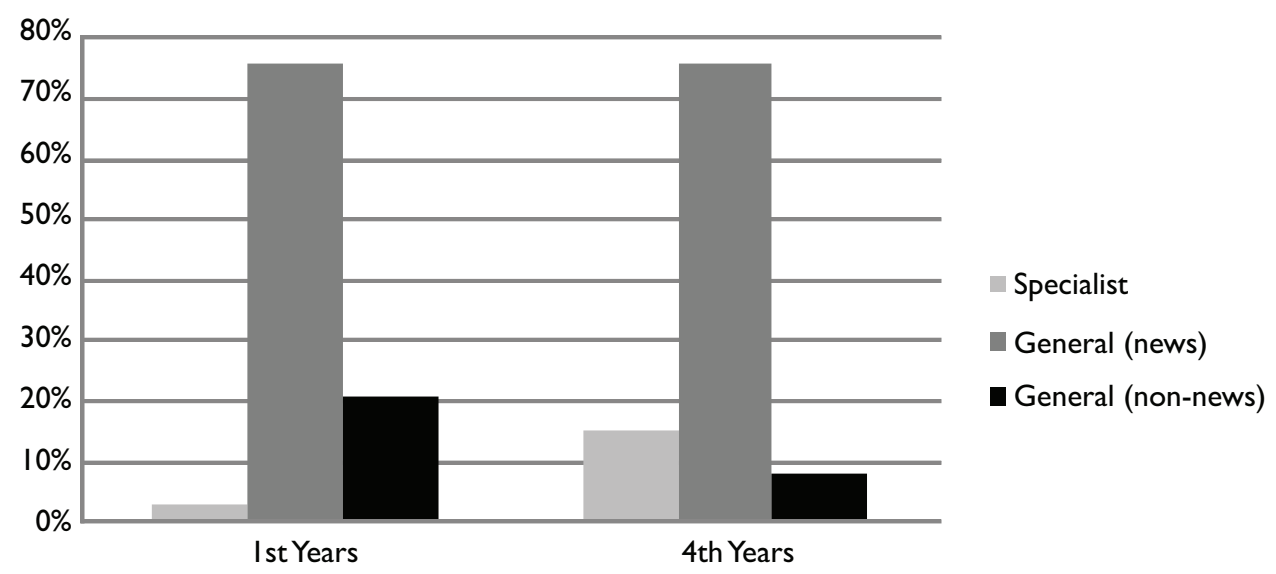

The survey instrument also asked students to list as many economic or business commentators as possible. Figure 2 depicts the mean number of economic commentators listed by each sub-sample. The difference in the number of commentators named was significant between males and females in both the first-year and fourthyear samples. The difference between first-year and fourth-year samples was not significant. This evidence provides support for $\mathrm{H}_{4}$ but not for $\mathrm{H}_{3}$.

\section{FIGURE 2: NUMBER OF ECONOMIC COMMENTATORS NAMED}

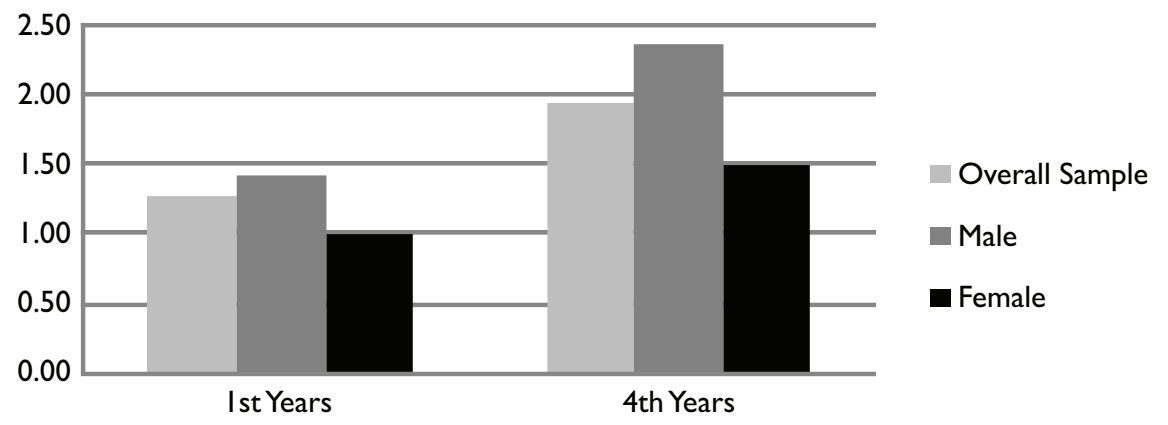

The survey data discussed up to this point relate to the use of media which are consumed passively by readers, viewers and listeners. A range of new media forms such as blogs and discussion boards have emerged which allow users to interact with content providers and one another. However, prior research has indicated students are less willing to engage with such fora for academic purposes (Cole, 2009; Madge et al., 2009), notwithstanding using similar platforms for social purposes. Respondents to the survey were asked to indicate the frequency and nature of their use of business-/economic-focused discussion fora and blogs. Table 4 summarises the student responses. 
Doran, Healy, McCutcheon and O'Callaghan

TABLE 4: USE OF BUSINESS/ECONOMIC DISCUSSION BOARDS AND BLOGS

\begin{tabular}{lcc}
\hline & First Years & Fourth Years \\
\hline Never & $70 \%$ & $56 \%$ \\
Read occasionally & $21 \%$ & $27 \%$ \\
Read regularly & $4 \%$ & $15 \%$ \\
Post occasionally & $4 \%$ & $1 \%$ \\
Post regularly & $1 \%$ & $0 \%$ \\
\hline
\end{tabular}

The findings show that the use of these media is generally low, with a majority in both cohorts never accessing these media. Furthermore, it can be seen that those respondents who were users did not use the interactive features of these media to any significant extent and were 'lurkers' who tended to read rather than post themselves. Chi-squared tests were used to test the significance of differences between males and females and first- and fourth-year samples in reported use of discussion boards and blogs. Differences were not significant in either case. This evidence does not support $\mathrm{H}_{3}$ or $\mathrm{H}_{4}$. Table 5 summaries the evidence from each of the measures of engagement used in this study and indicates whether the findings support the hypotheses proposed on engagement. 'Yes' indicates that, at a 5 per cent level of significance, the evidence supports the relevant hypothesis. 'No' indicates the evidence does not support the relevant hypothesis.

TABLE 5: SUMMARY OF EVIDENCE ON ENGAGEMENT

\begin{tabular}{lcccc}
\hline Hypotheses & $\begin{array}{c}\text { Frequency of } \\
\text { Use of Range } \\
\text { of Business } \\
\text { Media }\end{array}$ & $\begin{array}{c}\text { Measure of Engagement } \\
\text { Newspaper } \\
\text { Last Read }\end{array}$ & $\begin{array}{c}\text { Number of } \\
\text { Economic } \\
\text { Commentators } \\
\text { Named }\end{array}$ & $\begin{array}{c}\text { Use of Business } \\
\text { Discussion } \\
\text { Boards and } \\
\text { Blogs }\end{array}$ \\
\hline $\begin{array}{l}\mathbf{H}_{3} \text { : Fourth-year } \\
\text { respondents exhibit } \\
\text { higher levels of } \\
\text { engagement with } \\
\text { business media than first- } \\
\text { year respondents }\end{array}$ & Yes & Yes & No & No \\
$\begin{array}{l}\mathbf{H}_{4} \text { : Male and female } \\
\text { respondents exhibit } \\
\text { different levels of } \\
\text { engagement with } \\
\text { business media }\end{array}$ & No & No & & \\
\hline
\end{tabular}

"Differences between male and female respondents were statistically significant in the first-year group only

In summary, as shown in Table 5, the research findings regarding engagement with business media provide some support for $\mathrm{H}_{3}$ and generally do not support $\mathrm{H}_{4}$. Differences between male and female respondent engagement is only apparent on some measures and is generally not statistically significant. 


\section{Discrimination between Media Sources}

Prior research has highlighted concerns about students' ability to take a critical perspective on the information they consume. One aspect of this is the ability of students to make subjective judgements about the reliability of various news sources. It is suggested that students who rate the reliability of different media sources differently are viewed as exhibiting discrimination, whereas students who rate the reliability of all sources equally are not. The measure of discrimination used in this study therefore is the standard deviation of each respondent's reliability ratings (on a scale of $1-4$, where 4 is 'very reliable') of six print and television news media sources. Mean standard deviations for first- and fourth-year samples are displayed in Figure 3.

FIGURE 3: MEAN STANDARD DEVIATIONS OF RELIABILITY RATINGS

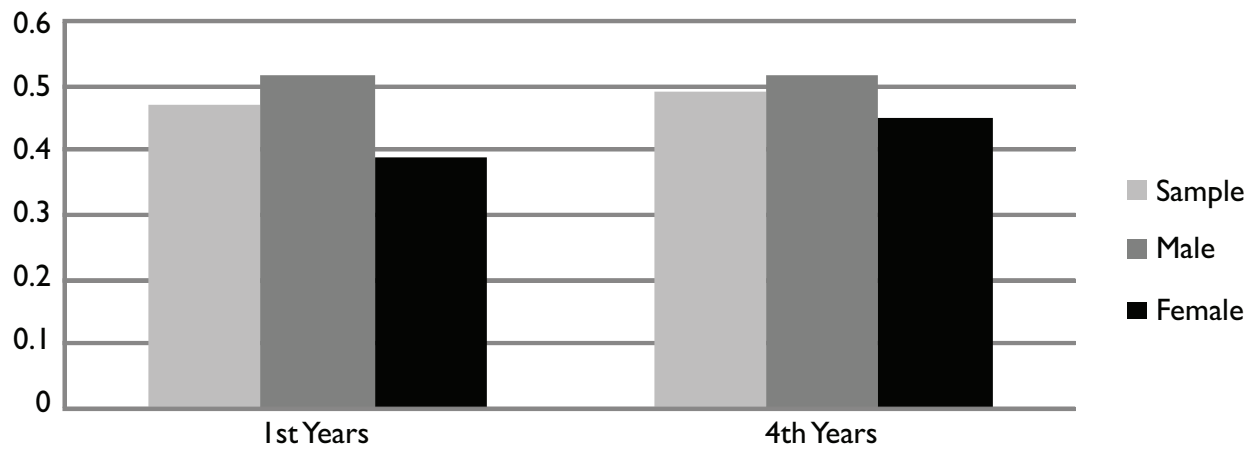

For both year groups combined the maximum and minimum observations and the standard deviation respectively were 1.51, 0 and 0.33 . Both first- and fourth-year students rated off-line sources as considerably more reliable than online sources and the pattern was similar among both first and fourth years. The level of discrimination did not differ between the first-year and fourth-year groups. Males in both first- and fourth-year samples displayed a greater variation in reliability ratings than females; using a Mann-Whitney $U$ test, the difference was significant, at a 10 per cent level, in the first-year sample. Female fourth-year student ratings had higher variation than their first-year counterparts but this difference was not statistically significant. Male ratings were more dispersed than female scores, with standard deviations of 0.34 and 0.30 respectively. In summary, male scores were generally higher and more dispersed than female scores.

These findings do not support $\mathrm{H}_{5}$ : no significant differences are evident between the first- and fourth-year samples. There is limited evidence for $\mathrm{H}_{6}-$ males in the first-year sample do display greater discrimination than females but this difference is not found in the fourth-year sample.

\section{DISCUSSION AND CONCLUSIONS}

This study compares first- and fourth-year students' knowledge of the business environment, and their engagement with and discrimination between various business 
media. The study finds that fourth-year students are significantly more knowledgeable than first years, based on the administration of a business knowledge quiz. In addition to the progression from first to fourth year, other contributing factors might include age, increased maturity and engagement with the employment market. Male students scored significantly higher than females. This may have implications for their level of participation in broader classroom activities and discussion. Females at this stage may be more focused on the narrower curriculum and these differences may be less apparent at a later stage. Further research of trainee accountants would be useful in this context. It was also noted that across all three aspects of the research findings reported in this study (level of business knowledge, as represented by the quiz score; media engagement score; and media discrimination score), the results for male students exhibited greater dispersion, with more 'high' and more 'low' observations, than in the results for female students.

Media engagement by fourth years was also greater than that of first years on some measures. However, in most of the measures used there were no significant differences between male and female students. Interestingly, the only aspect of engagement returning a significant difference between male and female students was in the number of economic commentators each could name, and in this measure there was no significant difference between the first- and fourth-year samples. These findings suggest that the concept of engagement is multifaceted; individual students may exhibit high levels of engagement on some measures but not on others. The choice of engagement measure(s) in future research initiatives therefore requires careful consideration.

The study also shows that students, contrary to popular belief, made little active use of interactive media in engaging with the business environment, with a majority in both cohorts never accessing these media. Those who did access them were passive readers rather than active contributors, corresponding with the findings of previous research. The use of social media for broader business purposes is still evolving. Research on the manner in which students use these media is an area that will need to be revised in future research as patterns of use in the broader business media change over time.

The level of discrimination between different media sources did not differ between fourth years and first years. The finding of no overall difference in the level of media discrimination runs counter to evidence emerging elsewhere from the survey where significant differences were found between fourth-year and firstyear students in the level of their engagement with media. In this context, it is worth noting that Metzger et al. (2003) found that students ascribed greater levels of credibility to information from across a range of media sources than did the general adult population and were significantly less likely to verify that information. There was a significant difference between first-year males and females in their level of discrimination, with males exhibiting a higher level of discrimination in first year. The gender gap in discrimination is not apparent in fourth year. This study indicates that fourth-year students are more knowledgeable about the broader business environment and better able to engage with news media. There is no evidence of a higher level of discrimination among fourth-year students overall than among first years. It might have been expected that after four years of an undergraduate business 
programme students would exhibit higher levels of discrimination, but this is not supported. This would be particularly relevant in an area such as accounting where professional careers require a sceptical stance towards all information sources.

This study has provided an initial exploration of the reported interaction with news media of a subset of third level students, studying Accounting and Finance programmes at one Irish university. The data presented are that of reported use rather than actual use as evidenced by, for example, the tracking of online access patterns and information retrieval behaviours. It would also be interesting to consider and provide evidence as to whether those who have more knowledge of the broader business environment, outside the curriculum, and engage more with news media perform better at university; however, given the anonymous nature of the research instrument, this was not possible. Further research, using a cohort approach to tracking a group of students over several years of their study, is needed to yield greater insights into the development of information literacy skills in Accounting and Finance students over the duration of their studies. Notwithstanding its limitations, the evidence provides a baseline for future research, offering a useful insight into the existing levels of business knowledge and engagement with business media of Irish third level students.

\section{REFERENCES}

Chan, J. and Leung, L. (2005). Lifestyles, Reliance on Traditional News Media and Online News Adoption, New Media \& Society, Vol. 7, No. 3, pp. 357-382.

Cole, M. (2009). Using Wiki Technology to Support Student Engagement: Lessons from the Trenches, Computers \& Education, Vol. 53, No. 1, pp. 141-146.

Connaway, L. and Dickey, T. (2010). The Digital Information Seeker: Report of the Findings from Selected OCLC, RIN, and JISC User Behaviour Projects, Bristol: Higher Education Funding Council for England on behalf of the Joint Information Systems Council, available from: <http://www.jisc.ac.uk/publications/reports/2010/digitalinformationseekers.aspx>, last accessed 15 August 2012.

D'Haenens, L., Jankowski, N. and Heuvelman, A. (2004). News in Online and Print Newspapers: Differences in Reader Consumption and Recall, New Media \& Society, Vol. 6, No. 3, pp. 363-383.

Flanagin, A. and Metzger, M. (2007). The Role of Site Features, User Attributes, and Information Verification Behaviours on the Perceived Credibility of Web-Based Information, New Media \& Society, Vol. 9, No. 2, pp. 319-324.

Graham, L. and Metaxas, P. (2003). 'Of Course It's True; I Saw It on the Internet!' Critical Thinking in the Internet Era, Communications of the ACM, Vol. 46, No. 5, pp. 71-75.

Griffiths, J. and Brophy, P. (2005). Student Searching Behavior and the Web: Use of Academic Resources and Google, Library Trends, Vol. 53, No. 4, pp. 539-554.

Grimes, D. and Boening, C. (2001). Worries with the Web: A Look at Student Use of Web Resources, College E Research Libraries, January, Vol. 62, No. 1, pp. 11-22.

Ha, L. and Fang, L. (2012). Internet Experience and Time Displacement of Traditional News Media Use: An Application of the Theory of the Niche, Telematics and Informatics, Vol. 29, No. 2, pp. 177-186.

Hampton-Reeves, S., Mashiter, C., Westaway, J., Lumsden, P., Day, H., Hewerston, H. and Hart, A. (2009). Students' Use of Research Content in Teaching and Learning: A Report of the 
Doran, Healy, McCutcheon and $\mathrm{O}^{\prime}$ Callaghan

Joint Information Systems Council (JISC), Preston: Centre for Research-Informed Teaching, University of Central Lancashire, available from: <http://www.jisc.ac.uk/media/ documents/aboutus/workinggroups/studentsuseresearchcontent.pdf $>$, last accessed 15 August 2012.

International Federation of Accountants (2010), Handbook of International Education Pronouncements, New York, NY: IFAC.

Kirkwood, A. and Price, L. (2005). Learners and Learning in the Twenty-First Century: What Do We Know about Students' Attitudes towards and Experiences of Information and Communications Technologies that Will Help Us Design Courses?, Studies in Higher Education, Vol. 30, No. 3, pp. 257-274.

Madge, C., Meek, J., Wellens, J. and Hooley, T. (2009). Facebook, Social Integration and Informal Learning at University: 'It Is More for Socialising and Talking to Friends about Work than for actually Doing Work', Learning, Media and Technology, Vol. 34, No. 2, pp. 141-155.

McDowell, L. (2002). Electronic Information Resources in Undergraduate Education: An Exploratory Study of Opportunities for Student Learning and Independence, British Journal of Educational Technology, Vol. 33, No. 3, pp. 255-266.

Metzger, M., Flanagin, A. and Zwarun, L. (2003). College Student Web Use, Perceptions of Information Credibility, and Verification Behavior, Computers \& Education, Vol. 41, No. 3, pp. 271-290.

Mitchelstein, E. and Boczkowski, P. (2010). Online News Consumption Research: An Assessment of Past Work and an Agenda for the Future, New Media \& Society, Vol. 12, No. 7, pp. 1085-1102.

Saunders, M., Lewis, P. and Thornhill, A. (2009). Research Methods for Business Students, fifth edition, Harlow: FT Prentice Hall.

Scholz-Crane, A. (1998). Evaluating the Future: A Preliminary Study of the Process of How Undergraduate Students Evaluate Web Sources, Reference Services Review, Vol. 26, Nos. 3/4, pp. 53-60.

Tseng, S. and Fogg, B. (1999). Credibility and Computing Technology, Communications of the ACM, Vol. 42, No. 5, pp. 39-44.

Wathen, C.N. and Burkell, J. (2002). Believe It or Not: Factors Influencing Credibility on the Web, Journal of the American Society for Information Science and Technology, Vol. 53, No. 2, pp. 134-144.

Wong, W., Stelmaszewska, H., Barn, B., Bhimani, N. and Barn, S. (2009). JISC User Behaviour Observational Study: User Behaviour in Resource Discovery, Final Report, Bristol: Higher Education Funding Council for England on behalf of the Joint Information Systems Council, available from: <http://www.jisc.ac.uk/media/documents/publications/ programme/2010/ubirdfinalreport.pdf>, last accessed 25 February 2011. 